\title{
What Makes a Carpet Fly? Cultural Studies in the Indian Ocean
}

\author{
Transforming Cultures eJournal, \\ Vol. 3 No 2, November 2008 \\ http://epress.lib.uts.edu.au/journals/TfC
}

\section{Stephen Muecke ${ }^{1}$}

\begin{abstract}
This paper aims to open up a cultural studies conversation on the Indian Ocean. Knowledge of the Indian Ocean should be born of the problems encountered in situ, rather than viewed and assessed from afar in erstwhile colonial centres. Networks and institutional links have to be created to sustain an interdisciplinary conversation leading to this decolonisation of knowledge. In investigating the interplay of commerce and culture, this paper abandons the critical separation of the two in favour of a critical engagement with forces of globalisation. As a precolonial global economy, the Indian Ocean offers considerable historical depth to the current ranking of economic powers. But within a general problematic of the theory of value, there is no doubt that cultural forms (narratives, myths religious beliefs, artefacts) are fundamental to the organising forces of trade, and not just 'adding value' in market transactions.
\end{abstract}

Economics aims for the objective calculation of value in the creation and exchange of goods and services, but that value is imbued at every stage with less calculable, but no less essential, human values, and it is in the area of the analysis of these latter values that cultural studies works. The mutual imbrication of the materials, events and texts referred to by the terms 'economy' and 'culture' is suggested by the existence of a field of study, that of 'cultural economy' as elaborated in the contents of books such as the one of that title edited by Paul du Gay and Michael Pryke (2002). This imbrication can be conceived of in more than one way.

On the one hand we know that economic matters, even if pursued with an insistence on the cold hard facts, are organised in themselves 'like a culture' to the extent that their exchange runs smoothly because of a thousand unwritten rules of behaviour. Such effects are highlighted whenever a modern management consultant advises a failing

\footnotetext{
${ }^{1}$ Stephen Muecke is Professor of Cultural Studies at the University of Technology Sydney. He specialises in Aboriginal history and culture and Australian popular culture and is currently engaged on a longrunning ARC funded project on culture and commerce in the Indian Ocean Region.
} 
company to 'change its culture', or, historically in the Indian Ocean, where traders working the monsoon routes learnt each others' languages and customs, and exchanged stories as well as goods. You have to tell a good story to make a good sale: a carpet is not just a carpet, you have to make it fly. Products, says Appadhurai, are goods that have 'careers', (see Michael Callon et al 2002:122-200) and each is 'defined by a combination of characteristics that establish its singularity' (2002:198)

On the other hand, of course, we are aware that cultures themselves are traded. It was in this way that Western modernity was sold into other markets, as if that kind of modernity itself was the real purchase ('a better future') and the little gadget or commodity (some 'labour-saving device') were its mere symptom. So it is this latter sense of economics of culture (rather than the culture of economics) that I will pursue in the rest of this paper, and I will do it by telling five little stories about things that cultural studies makes visible in that particular culture, aspects of the field that weren't particularly the focus of Indian Ocean studies before. These are qualities, distributed in the space of the Indian Ocean, that effect what counts as our knowledge as researchers and intersects with calculations of value - human or commodity value.

These are transnational stories. They are about cultures, shot-through with values, that emerge on the high seas, as it were, as one sits on a cargo increasing steadily in value as one gets closer to the place where that stuff is highly sought after. In that sort of situation, the comparative analysis of national wealth does not seem to be the best kind of approach, but that is how the data has been accumulated.

\section{How many countries of the Indian Ocean have modern art museums?}

Let me tell you a story about Madagascar. In July 2003 the photographer Max Pam and I were wandering around Hellville in North-West Madagascar. We are in the main square of the town, having just withdrawn a few million Madagascan francs from the bank which had two other clients, a Swedish couple. As we cross the square a dog is run over by a Renault 4 moving at a leisurely pace. The driver slows down a bit at the yelps of the dog, but keeps going. The mongrel, thin and mangy, gets up with difficulty and hobbles off. Then we continue on our search for the museum, which is only a few streets away. It is closed, so we inquire at the restaurant next door, empty after lunch: 
-Il est fermé, le musée?

-Ah, oui.

- Mais il y a quelque chose dedans?

—oh oui, il est plein d'objets, mais il est fermé depuis longtemps. ${ }^{2}$

So Max takes a photo of the woman in red shoes; she is heading off to the next big town to look for work. ${ }^{3}$

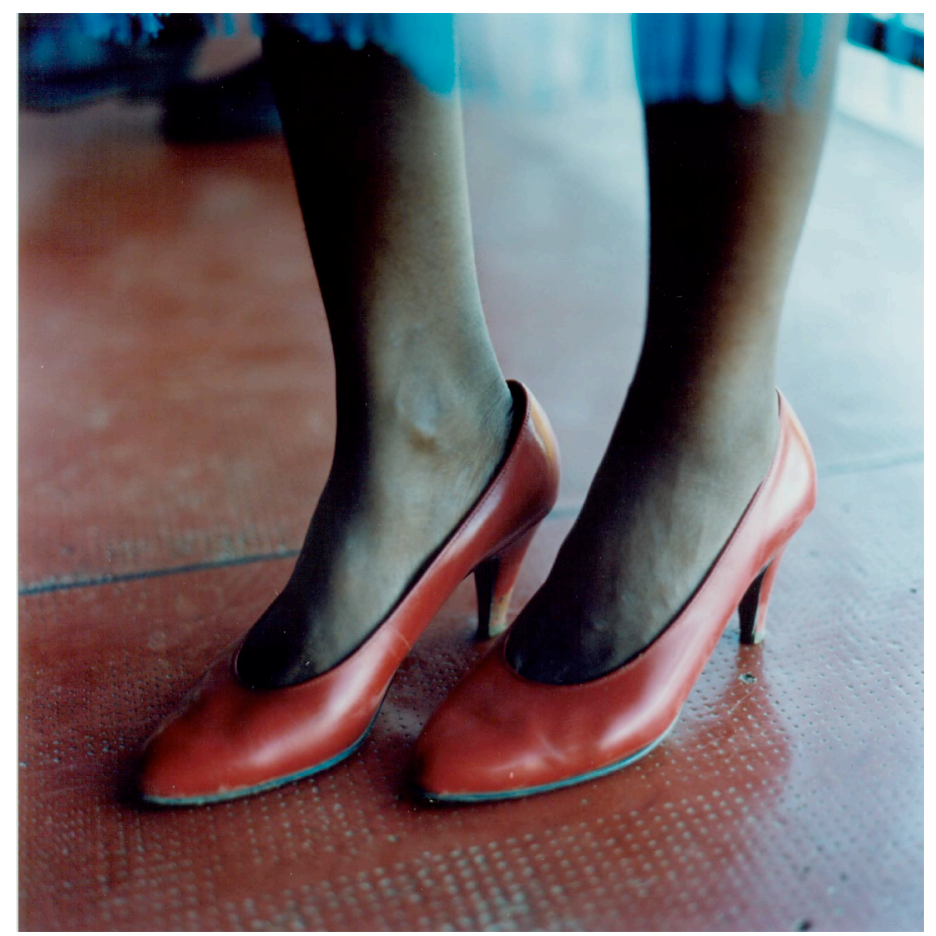

My story about tourism, poverty and a closed museum is supposed to lead to further inquiries about wealth and cultural expression (value and values if you like). Let's investigate. How many countries of the Indian Ocean have modern art museums? I am shifting the parameters here for a reason. Historical and ethnographic museums, like the one were didn't see inside in Hellville, are a first step. They can be fairly simply put together from available local collections and satisfy the nationalist demand for heritage and the tourist demand for cultural specificity, or local colour.

But modern art museums signal something altogether different, a cultural complex

\footnotetext{
2 'The museum is closed?' "Ah, yes.' 'But it does have stuff in it?' 'Oh yes, it is full of things, but it has been closed for a while now.'

${ }^{3}$ This photograph will appear in Stephen Muecke and Max Pam, Contingency in Madagascar, Mácula de Plata, Gijon: Spain, forthcoming.
} 
produced out of: a dense urban culture, a tertiary training institute, like an art school; and the circulation of people, materials (exhibitions) and ideas (seminars, lectures, etc) on a global scale. All this because it is not sufficient for the museum to be a repository of modern art, it has to demonstrate that it has the capacity to continue to produce contemporary art, leading eventually to global phenomena like Biennales. How many countries of the Indian Ocean have Modern Art Museums? Perhaps only Singapore, Réunion, the Maldives, Southern Africa and Australia, the most 'western' of the Indian Ocean countries. These countries have been able to invest in a luxury culture (over and above the basic requirement for industry and trade to keep the economy ticking over), but culture that is nonetheless necessary for these countries to be fully-fledged members of the Modern Club, to aspire to full 'development' as it were.

We are talking here about a version of cultural capital - Pierre Bourdieu's category - a necessary 'attractor' for real capital, as the cities involved are able to brand themselves 'creative cities'. And let's not forget the citizens who want their national budget to be invested this way, who want varied and interesting cultural stimulus, or who are human capital themselves, exportable talent, or who are attracted from elsewhere to the creative precincts of these cities.

So that is one way to make the magic carpet fly. It is not just a floor covering, not just craft or folk heritage, no, this kilim from Afghanistan with its AK47s and tanks is a work of art. The proof? Well, obviously it is hanging on the wall, gaining value at 10$15 \%$-almost flying!

\section{Repetition and the multitude}

Now for my second story, about football: a sport but also a culture. Now we can say that every Indian Ocean country has a soccer team, even the Comores. Such teams function to build national identity, and also regional identity. Les Jeux des Isles de l'Océan Indien is one of the few organisations through which the Indian Ocean islands meet as a region on an annual basis.

The understanding of such events can most appropriately be approached with cultural studies methods. Unlike the singularities and contingencies of history, such events are staged, repeated performances, backed up by institutions, but constituted by ceremonial 
rituals as complex as the traditional rituals of the investiture of African kings. The codes are layered: narratives, song, ritual separation of men, women and children, the iconic sacred prize object (the medal or the cup), and so on-all the stuff of anthropological analysis, but here applied, in typical cultural studies style, to contemporary cultures.

In the year 2000 I travelled to Nairobi with my son Hugo and we were told even before we had arrived at our hotel that the Kenyan soccer team would be staying there. We met them, and learnt that the game against the Cameroons would be on the next day. In the morning we crammed into a taxi-brousse to cross the busy capital, and walked the last couple of kilometres along with the crowd gathering in size and momentum. Once we had arrived the stadium, it was by no means clear how or where to buy a ticket. Police on horseback were shepherding the crowd, which now had flows taking off as people rushed to a collapsed cyclone fence or to climb a wall. The atmosphere was getting tense. A couple of shots were fired by the police and by this time Hugo's thirteen yearold knees were banging together and he begged to leave.

Disappointment, failure to participate and observe. It was as if this Kenyan crowd had intensified and solidified into a head full of Mau-mau memories as it spat out these two pale foreign elements and sent them back to their hotel to watch the game, or its remains, on fuzzy TV.

This, then, is another way that value is attributed beyond the item and its commodity value. I have tried with this story to evoke the power of the swarm, the multitude, and again, the figure of repetition. The singular isolated object never made sense anyway. It can be made sense of structurally in relation to the other elements of a system, but, no longer being a structuralist, I would want to argue that these things make sense, or at least impose some sense, when they come in a rush, as a mass. This particular carpet, one might say, is better than all those other carpets which you know and remember through those percussive effects you sensed a million times before in similar transactions with things, in the resonance of the market place, a story about Sindbad, a multitude of shock waves through crowded time. 


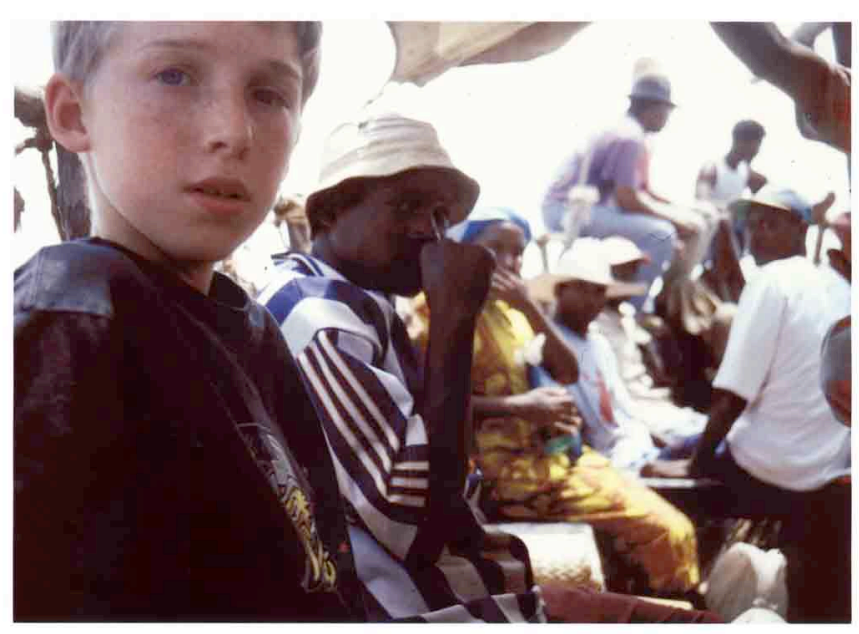

Photo taken by Stephen Muecke

\section{Transnational identities}

My third story is about Bollywood, so it is a story about the stories India is trading around the region and the world. This flow of story-commodities has been circulating ever since Sindbad, but is now going beyond the Indian Ocean region to reach the Indian diaspora of some 20 million people. Writing in the Asia Times Online, Priyanka Bhardwaj tells us:

Koi Mil Gaya made \$10 million in India, \$1.9 million from the US market and 1.6 million pounds in Britain; Kal Ho Na Ho made \$8 million domestically, $\$ 700,000$ in the US and 600,000 pounds in the UK; while Chalte-Chalte earned \$4.5 million at home, \$900,000 in America and 700,000 pounds in Britain. Dilwale Dulhaniya Le Jayenge made \$5 million abroad. And Rang de Basanti, a recent Bollywood release, has collected $\$ 6$ million abroad in just six weeks.

With $30 \%$ of the overseas revenue coming tax-free from the US, and another big slice from the UK, the money is not in the export sector in the direction of Dar-es-Salaam or Mauritius, but there, at every video-night, the Bollywood formula of song and dance, romance and action provides a cultural focus which is an alternative to Hollywood. It is an entertainment of excess without the need to edit out ideology or nudity.

The globalisation of Bollywood has been encouraged by the investment of countries like Singapore, South Korea and Poland offering their own countries as overseas location shoots, which in turn encourage Indian tourists to visit those countries. 
There is absolutely nothing new in what I have said about the globalisation of Bollywood. Reduced to the dollar, it is the same as the trade in any other commodity, like rice. But rice responds to human needs in a much simpler way than a cultural product. A film has to respond to very particular human desires in a subtle yet spectacular narrative way. Toby Miller, well-known for his book Global Hollywood (2001), recently spoke to me about the general decline in US export markets, and halfjokingly said that America doesn't export anything anymore, no automobiles, electronics, etc, but its major export remains, he suggested, 'subjectivities', and this is of course via Hollywood narratives. A subjectivity is just a model for how a person can become, and Bollywood necessarily fulfills the same function, but to an alternative global audience, with different culturally ascribed aspects of 'personhood'.

With film, all the aspects typical of the kind of cultural analysis I have suggested the Indian Ocean might 'need', are still there: repetition, ritual, narrative, performance or spectacle, and even the aura of the sacred. All these feed into the construction of identity, which I just defined as 'culturally ascribed aspects of 'personhood'. Previous Indian Ocean studies have described the emergence of Indian Ocean identities, like that of Swahili groups, or seaside cultures, or religious identities emerging out of the spread of Islam. Film, the STAR TV network, or TF1 and canal+ beaming into the francophone areas of the Indian Ocean will not determine or impose new identities, but aspects of them will be layered over and seep into the older ones. They can also encourage 'lines of flight' for those people who feel they are stuck somewhere, and want to move towards where there is more opportunity and hope. The desire for 'existential mobility' as Ghassan Hage calls it, the state of being on the road to somewhere better, even if one is still in the one place, is at the heart all diaspora and migration (Hage 2006).

On arrival, the place of hope may turn out to be a big disappointment, and that is the theme of my final story, about how politics can literally draw a line in the sea, when the movement of capital is encouraged, but that of people is not.

\section{National Disgrace}

My fourth story is one aspect of the 'culture' of contemporary security in the Indian Ocean. In principle, the application of the law for security purposes has nothing to do 
with culture, nor should it. But when a government agency transgresses the applicability of the law, distorting it for political purpose, then it partakes of the excessiveness of culture. Why excess? Because government in this case is doing more than just govern. The Australian government in 2001 generated a national and international 'incident' or scandal, by refusing its international maritime responsibilities.

Known as 'the children overboard affair', this political scandal arose when the government claimed that a number of children had been thrown overboard from a suspected illegal entry vessel (or SIEV) which had been intercepted by HMAS Adelaide off Christmas Island. The vessel, designated SIEV 4, was carrying a number of asylum seekers, and believed to be operated by people smugglers. Heavy-handed tactics were then used by the Australian Navy to try to force the vessel to land in Indonesia. The 'children overboard' claim was first announced by the then Minister for Immigration, Philip Ruddock on 7 October 2001, and repeated in subsequent days and weeks by senior Government ministers, including the Minister for Defence, Peter Reith, and Prime Minister John Howard.

The motivation of those allegedly throwing their children overboard, according to those who reported the incident, was to effectively force the Royal Australian Navy to rescue the children and their parents. The claim was used to cast doubt on the passengers of SIEV 4 as genuine refugees, instead characterising them as people prepared to use unscrupulous means to gain illegal entry into Australia. A subsequent inquiry by a Senate select committee found that not only was the claim untrue, but that the government knew the claim to be untrue before the Federal elections, which were held one month later.

Thus was Australian history crafted out of the contingencies of a government creating its own exceptions from law and from what are sometimes called 'common decency' or 'respect for humanity', very fluid cultural categories. As opposed to the crafting of individual subjectivities I spoke about in relation to movie narratives, this kind of event participates in the crafting of a national identity: a new 'white Australian' fortress prepared to get tough on foreigners 'of middle eastern appearance' as the newspaper phrase has it. 


\section{Ivory speaks}

In traditional Indian Ocean trade, commodity value is obviously crucial, and it governs the movement of goods. The trade in ivory, however, is a stunning case study of the subsequent factoring in of 'natural' values into the trade in this particular commodity. Ivory was in abundance in Africa in the pre-colonial period. It was not treated as a precious substance. Resistant to termites, it was used for palisades or cattle yards in villages. This meant that traders from India could do good business, distributing ivory in the then global economy centered on the Indian Ocean, where it would be transformed into a luxury item, many times its original value. So a natural material, abundant in certain areas, is converted through the addition of cultural value into a precious material. Now, as ivory and elephants began to be threatened, values of course went up, but a new set of values began to assert itself via the argument that is put by elephants, so to speak, through their environmentalist human advocates. The arguments trumpeted by the suffering elephants are about sustainability and ecological balance in Africa (see Charis Thompson 2002). By integrating the concept of value, cultural values (an appreciation of the beauty of a carved ivory artifact or, conversely, the compassion for elephants criminally slaughtered) need not contradict or compete with the corporation's need to profit, but now such things have to be taken into 'account', as the corporation and its shareholders are convinced about the unsustainability of a purely exploitative relationship with nature where the value flows only one way and is assumed to be limitless. More recently we note, the ban on the sale of ivory was lifted so that countries like Zambia could release their stockpiles of ivory.

\section{Conclusion}

When people ask me what cultural studies is, my short answer is that we do the cultural analysis in conjunction with historical analysis and sometimes political economy. Cultural analysis, as my examples illustrated, draws on anthropological categories like ritual and performance, and, supplemented with more literary understandings of code, narrative and genre, begins to probe the mysterious forces of culture that are not reducible to utility, function, or symbolic display. The very repetition of cultural events reinforces the associated values for the participants, making them feel a bit more Kenyan or Mauritian or even 'Indian-oceanic' for the occasion. This feeling swells with the multitude. But this can be a political and economic multitude as well, because it can rise up in revolt or refuse to participate in organised labour. But the economic must 
always be via the multitude. The production and consumption of goods creates basic economic value, as the multiple containers are loaded up for export. And for those who stand to profit, the excitement grows, as 'fabulous' wealth is promised. Fabulous indeed are the stories that circulate over and above the distribution of basic materials like rice, ivory, gold, carpets. It is through the tales that are spun about the commodities that values are added to value, for the market works on fictions, lending magic to the aura of the commodity. It will be its virtual westernness, its modernity, its eroticness or its exoticness that sells the object. In is not just Marx's observation of the fetish nature of the object that is relevant here; I have sought to stress the way products are vehicled by stories, the kinds of stories that generated the Fabulous East as a place to seek one's fortune, a fiction launching da Gama's fleet and only finishing perhaps with Conrad. Can we develop our knowledge of an area like the Indian Ocean-producing and trading in facts - without references to the narratives that underpin that trade. There are colonial fictions; how can we be sure our knowledge is not compromised by such a fictional framework? And there are post-colonial fabulations, stories that describe other kinds of becomings. In an essay on European modernity in its anthropological relations, Bruno Latour suggests that there are in fact core values that are the pillars for the colonial fiction, he designates them as Objectivity, Profitability and Efficiency (Latour 2007:22). In this essay I have been edging towards their $21^{\text {st }}$ century replacements: negotiability, enjoyability and sustainability. Negotiability, because in the calculation of economies of qualities one has to decide whose 'fiction' one is being enchanted by, following or rejecting; enjoyability, because it extends and broadens the meaning of 'profit'; and sustainability, because natural things are now demanding to be signatories in the contracts for industry and development.

My five stories were about five aspects that could be further pursued in the context of Indian Ocean Cultural Studies: cultural capital (which is the combination of infrastructure, human resources, cultural policies for the generation of prestige); the multitude as it relates both to the popularity of things (festivals and commodities, and the exploitability and danger of this multitude); individual subjectivity generated as one aligns a personal narrative with a national or transnational one; the calculation of natural wealth; and finally national identities, as they are forged through historical contingencies, in this case political transgression. 


\section{Bibliography}

Bhardwaj, Priyanka (19 May 2006) 'Foreign shoots spread Bollywood's reach', Asia Times Online.

Callon, Michel; Meadel. Cecile \& Rabeharisoa, Vololona (2002) 'The Economy of Qualities' Economy and Society, Vol. 31. No. 2: pp. 194-217.

Gay, Paul \& Pryke, Michael (eds.) (2002) Cultural Economy: Cultural Analysis And Commercial Life London: SAGE.

Hage, Ghassan (2006) 'Social Hope and Social Speed: On the Relation between Modes of Anticipation and Existential Mobility among Lebanese Migrants', at Cornell University Department of Anthropology Colloquium, 2 May 2006, Cornell University.

Latour, Bruno (2007) 'The Recall of Modernity_Anthropological Approaches', Cultural Studies Review, March, pp. 11-30.

Miller, Toby; Govil, Nitin; McMurria, John; Wang, Ting \& Maxwell, Richard (eds.) (2001) Global Hollywood, London : British Film Institute.

Thompson, Charis (2002) 'When Elephants Stand for Competing Philosophies of Nature: Amboseli National Park, Kenya', in John Law \& Annemarie Mol, (eds.) Complexities: Social Studies of Knowledge Practices, Durham Duke University Press. 